\title{
A study of the relationship of physical activity with scholastic performance and body mass index in children 12-18 years of age
}

\author{
Shashank Negi ${ }^{1},{ }^{*}$ B M John², Seema Patrikar ${ }^{3}$ \\ Sri Lanka Journal of Child Health, 2016: 45(1): 18-23
}

\begin{abstract}
Background: Studies on relationship between physical activity and academic performance have yielded variable results while its effect on body mass index (BMI) is clearer. There is a paucity of data on the subject in the Indian subcontinent.

Objectives: To explore the relationship between physical activity and academic performance in children between 12-18 years by assessing the correlation of physical activity with academic performance and BMI and analysing the association of duration of physical activity with academic performance and BMI.
\end{abstract}

Method: A cross-sectional study was carried out involving a questionnaire based interview of 400 students in the age group of 12-18 years. The data was then analysed using correlation and unpaired ttest by SPSS software version 14.0.

Results: A moderately good positive correlation was observed for physical activity with academic performance with $\mathrm{r}=+0.49$, whereas a mild negative correlation was observed for physical activity with body mass index with $r=-0.31$. A sub-group analysis using unpaired $\mathrm{t}$-test revealed that students indulging in physical activity of more than 1 hour duration had better academic performance and a healthier BMI as compared to students with physical activity less than or equal to 1 hour duration .

${ }^{1}$ Student, Armed Forces Medical College, Pune, India, ${ }^{2}$ Associate Professor, Department of Paediatrics, Command Hospital (Air Force), Bangalore, India, ${ }^{3}$ Lecturer in Statistics and Demography, Department Of Community Medicine, Armed Forces Medical College, Pune, India

*Correspondence: drbmj1972@yahoo.com

(Received on 17 January 2015: Accepted after revision on 20 February 2015)

The authors declare that there are no conflicts of interest

Personal funding was used for this project.

Open Access Article published under the Creative

Commons Attribution CC-BY License
Conclusions: Physical activity exhibits a positive relationship with academic performance and BMI in the adolescent age group.

DOI: http://dx.doi.org/10.4038/sljch.v45i1.8080

(Key words: Physical activity; body mass index; academic performance)

\section{Introduction}

Physical activity has a positive effect on children's health. It is also believed that regular physical activity is linked to enhancement of brain function and cognition. There are several hypothesized mechanisms for this such as increased blood and oxygen flow to the brain, increased levels of norepinephrine and endorphins with reduction of stress and an improvement of mood, and increased growth factors that help to create new nerve cells and support synaptic plasticity ${ }^{1-6}$. One meta-analysis showed a positive relation between physical activity and cognitive performance in school-age children in different measurement categories (perceptual skills, intelligence quotient, achievement, verbal tests, mathematic tests, memory, developmental level /academic readiness) ${ }^{7}$. Studies using electro cortical testing and functional MRI have also shown that greater amounts of physical activity are generally beneficial to cognitive processes that are related to the allocation of attentional resources and faster cognitive processing during stimulus encoding ${ }^{8,9}$. The time a student devotes to his physical activity is inversely proportional to his body mass index (BMI). BMI is a reliable indicator to classify an individual as healthy or otherwise. In the current environment, due to the increased syllabus and academic pressure, supplemented by pressure from parents, many students now prefer to study in their play time hours. This trend is fraught with the risk of increasing obesity. A review of literature shows that physical activity is variably correlated with scholastic performance and has a beneficial effect on maintaining $\mathrm{BMI}^{10-13}$. However, there is a paucity of data on this subject from our subcontinent. 


\section{Objectives}

To explore the relationship between physical activity and academic performance in children between 12-18 years by assessing the correlation of physical activity with academic performance and BMI and analysing the association of duration of physical activity with academic performance and BMI.

\section{Method}

A descriptive, cross-sectional study was carried out using a pre-designed questionnaire on students in the age group of 12-18 years, from four schools in Delhi and one college from Pune in India, over a three month period. The schools and college were chosen based on convenience. A sample size of 400 was considered to be adequate based on a correlation coefficient $\mathrm{r}=0.22(\alpha=0.05$, confidence interval of $95 \%$, and power of 0.8 ) in the pilot study which was carried out on 100 students. The questionnaire was used to assess the physical activity, academic performance and BMI of the students. Students categorized as not undertaking any physical activity were those who either had no sports, games or other activity as part of their daily regime or their daily physical activity was less than or equal to one hour duration. Student's average academic marks from the previous two years was calculated and this was considered as the index of student's scholastic performance for the study. The mean of the term exams for the school and semester exams for the college were taken for calculating one year's academic performance. Their BMI was calculated from the height and weight measured at the time of the data recording. Both non-government and government aided schools were included in the study. Children with any acute/chronic illness or disability were excluded from the study. Obtained data was analysed with Pearson correlation coefficient and unpaired t-test using SPSS software (Version 14.0). The study was approved by the ethical committee of Armed Forces Medical College, Pune.

\section{Results}

In our study of 400 students, 215 boys and 185 girls were interviewed using the questionnaire. They were from the $6^{\text {th }}$ standard to the first year of college and in the age bracket of 12-18 years. The distribution in different age groups showed 40.5\%, 26.8\% and $32.7 \%$ children in the age bracket of $12-14,14-16$ and 16-18 years respectively. Out of the 400 students studied, 170 were from private schools and 180 from government aided schools in Delhi. The remaining 50 students were selected from a college in Pune, Maharashtra. $63.7 \%$ of boys and $44.3 \%$ girls were engaged in some sort of physical activity or sports more than 1 hour as per definition used. The distribution of academic performance showed that $14 \%$ children had more than or equal to $90 \%$ marks, $23.7 \%$ between $75-89 \%, 29.3 \%$ between $60-74 \%$ and $33 \%$ had less than $60 \%$ marks, with the girls marginally outperforming the boys. The distribution of BMI in $\mathrm{kg} / \mathrm{m}^{2}$ showed $20 \%$ children to have BMI more than 30, 26.7\% with BMI 25-29.9, 29.3\% with BMI 18.5-24.9 and 24\% with BMI less than 18.5. On evaluation against the WHO $\mathrm{z}$ scores for BMI, $4.8 \%$ children had BMI $\mathrm{z}$ score more than 3 indicative of obesity while $25 \%$ had $\mathrm{z}$ score between 2-3 indicating a high prevalence of overweight children. Box plot analysis of the academic performance and BMI with respect to duration of physical activity showed that students devoting more time to their physical activity had better academic performance and lower BMI (Figures 1 \& 2). 


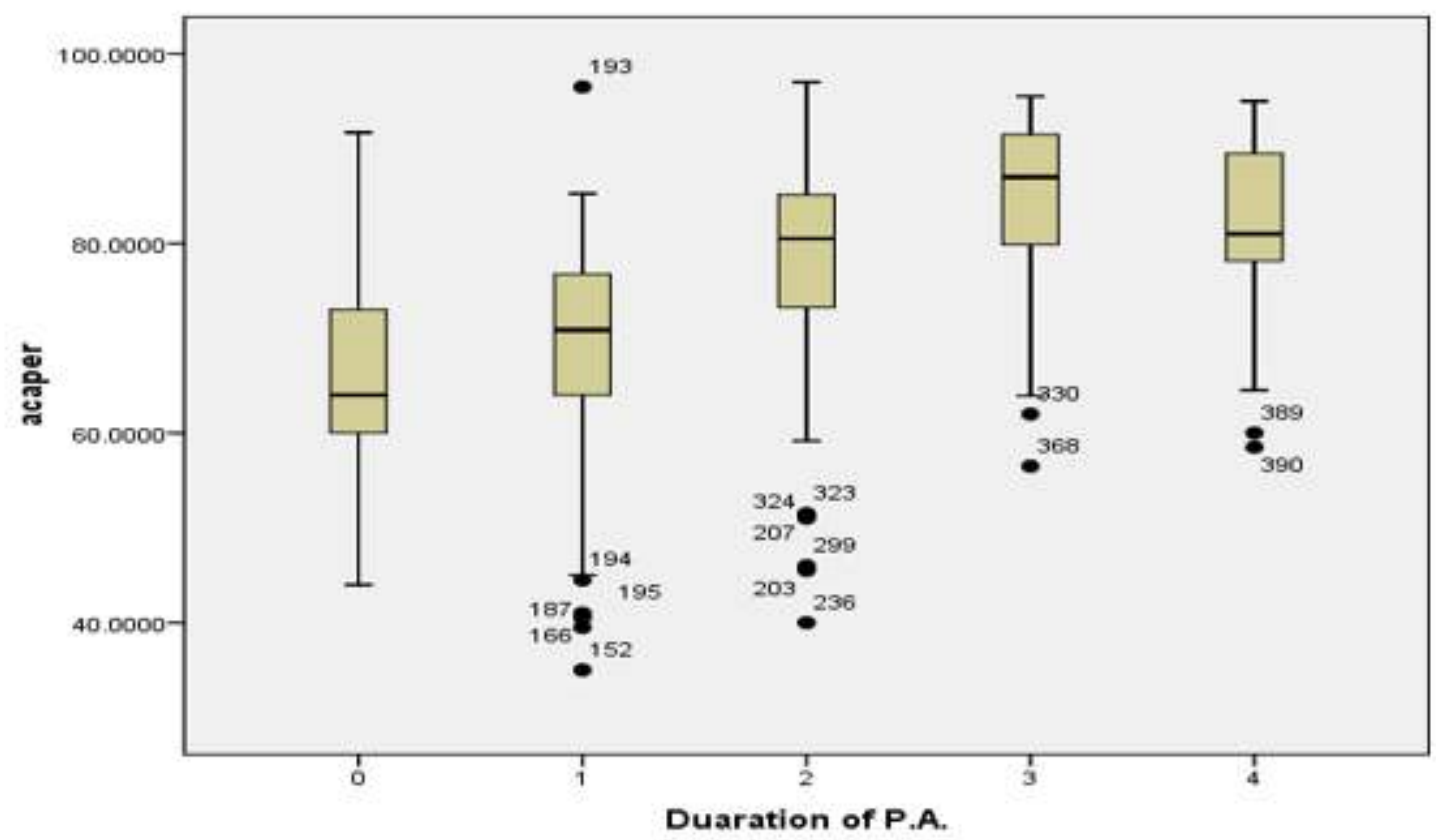

Figure 1: Box plot showing relationship of physical activity $(\mathrm{PA})$ in hours with academic performance

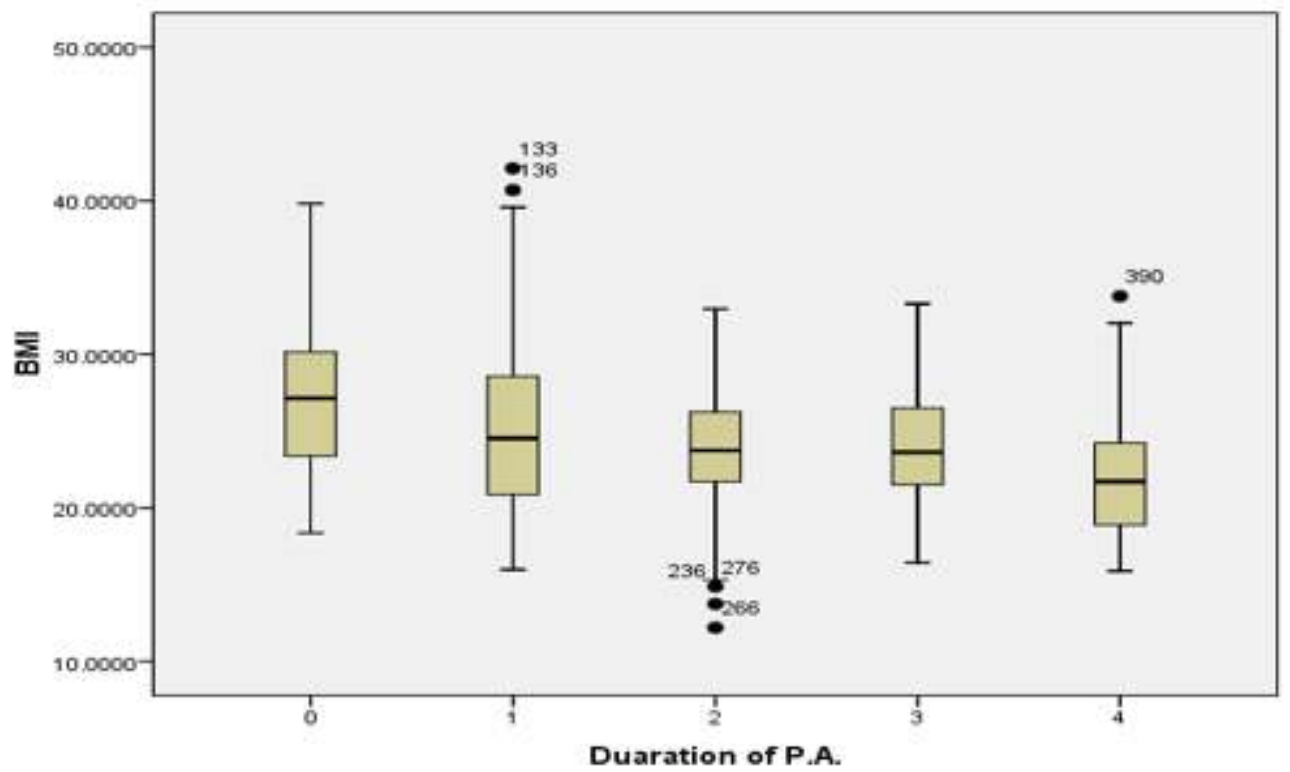

Figure 2: Box plot showing relationship of physical activity (PA) in hours with BMI (kg/m $\left.\mathrm{m}^{2}\right)$

Correlation coefficient was calculated for physical activity with academic performance and BMI. The correlation coefficient of physical activity with academic performance was $\mathrm{r}=+0.49(\mathrm{p}<0.001)$, indicating a moderate positive relationship of the two parameters. The correlation coefficient of physical activity with BMI was $\mathrm{r}=-0.31(\mathrm{p}<0.001)$, indicating a mild negative relationship of the two parameters. Table 1 shows the distribution of mean, standard deviation, standard error and $95 \%$ confidence interval of student's academic performance and BMI with different hours of physical activity. 
Table 1: Descriptive statistics of physical activity with academic performance and body mass index

\begin{tabular}{|c|c|c|c|c|c|c|c|c|c|c|c|}
\hline \multirow{3}{*}{$\begin{array}{c}\text { Duration of } \\
\text { physical } \\
\text { activity }\end{array}$} & \multirow[t]{3}{*}{$\mathrm{n}$} & \multicolumn{5}{|c|}{ Academic performance } & \multicolumn{5}{|c|}{ Body mass index } \\
\hline & & \multirow[t]{2}{*}{ Mean } & \multirow{2}{*}{ SD } & \multirow[t]{2}{*}{ SE } & \multicolumn{2}{|c|}{$95 \%$ CI } & \multirow{2}{*}{ Mean } & \multirow{2}{*}{ SD } & \multirow{2}{*}{ SE } & \multicolumn{2}{|c|}{$95 \% \mathrm{CI}$} \\
\hline & & & & & Upper & Lower & & & & Upper & Lower \\
\hline 0 hours & 181 & 66.80 & 11.39 & 1.01 & 64.80 & 68.80 & 26.90 & 4.73 & 0.419 & 26.07 & 27.74 \\
\hline 1 hour & 72 & 68.75 & 12.29 & 1.46 & 65.82 & 71.68 & 25.06 & 5.72 & 0.684 & 23.70 & 26.43 \\
\hline 2 hours & 62 & 77.98 & 10.17 & 0.885 & 76.23 & 79.73 & 23.51 & 3.97 & 0.345 & 22.83 & 24.19 \\
\hline 3 hours & 48 & 84.55 & 8.63 & 1.15 & 82.23 & 86.86 & 23.81 & 3.49 & 0.466 & 22.87 & 24.74 \\
\hline 4 hours & 37 & 80.22 & 11.46 & 2.95 & 73.81 & 86.56 & 22.43 & 5.13 & 1.32 & 19.59 & 25.27 \\
\hline Total & 400 & 73.82 & 12.63 & 0.631 & 72.58 & 75.06 & 24.86 & 4.78 & 0.239 & 24.39 & 25.33 \\
\hline
\end{tabular}

$n=$ number; $S D=$ standard deviation; $S E=$ standard error; $C I=$ confidence interval

It was observed that academic performance of students increased proportionately up to the $3^{\text {rd }}$ hour of physical activity but showed a marginal decline at the $4^{\text {th }}$ hour. However, BMI of students had a consistent relationship with physical activity. An unpaired $\mathrm{t}$-test was used for data analysis of the two groups with Group 1 consisting of students not taking part in any kind of physical activity or physical activity of less than or equal to 1 hour duration and Group 2 having students taking part in some form of physical activity of more than 1 hour duration (Table 2).

Table 2: Students unpaired t-test for differentiating academic performance and BMI of the 2 groups

\begin{tabular}{|c|c|c|c|c|c|c|c|}
\hline Criteria & Group & Number & Mean & SD & p value & \multicolumn{2}{|c|}{ 95\% CI } \\
\hline Academic & Group 1 & 253 & 67.49 & 11.72 & 0.000 & 65.85 & 69.14 \\
\cline { 2 - 5 } \cline { 6 - 7 } performance & Group 2 & 147 & 79.96 & 10.24 & & 78.54 & 81.37 \\
\hline Body mass & Group 1 & 253 & 26.25 & 5.17 & 0.000 & 25.52 & 26.98 \\
\cline { 2 - 6 } index & Group 2 & 147 & 23.51 & 3.93 & & 22.97 & 24.06 \\
\hline
\end{tabular}

$S D=$ standard deviation; $C I=$ confidence interval

It was observed that there was a significant difference in the students with the 2 groups of physical activity with respect to academic performance as well as BMI $(\mathrm{p}=0.000)$. The mean academic performance of students in group 1 was $67.49 \%$ whereas students of group 2 had a mean of $79.96 \%$. This indicated a positive mean difference of $12.46 \%$ favouring physical activity of more than 1 hour duration. Similarly, a mean difference of $2.738 \mathrm{~kg} / \mathrm{m}^{2}$ was observed in comparing the physical activity and BMI of the 2 groups again favouring the group with physical activity of more than 1 hour.

\section{Discussion}

Academic excellence is the most sought after priority in a student's life today due to growing competition in schools. Parents too consider academics to be the most important aspect of their adolescent child's life. Many students compromise on their sports and physical activity to concentrate on academics to achieve good grades particularly in high school. In this environment, the role of sports and other physical activities in improving physical and mental wellbeing has been forgotten or ignored. Physical activity not only helps a student remain fit but also helps in his learning process. Study of relationship between physical activity and brain function has been undertaken by researchers globally and has produced variable results ${ }^{8-10}$. On the other hand the relationship between physical activity and BMI is clearer with definite benefits of physical activity ${ }^{13}$. We found numerous studies exploring this relationship but very few were from the Indian subcontinent and none attempted the study model we chose.

Eitle $\mathrm{T}$ found that youth whose summer arrangements involved regular participation in organized activities showed significantly lower risk for obesity than other youth $^{14}$. In our study too we found that students who participated regularly in sports had a lower BMI. Coe et al found that students who met or exceeded guidelines for vigorous physical activity earned higher grades ${ }^{15}$. In our study we found out that the academic performance of the students increased proportionately with increasing hours of physical activity till a certain level. Ahamed et al found that school based physical activity did not compromise academic performance ${ }^{16}$. Our study showed that students who participated in physical activity performed better than students who did not. Carlson et $\mathrm{al}^{17}$ in their study reported a small but significant benefit for academic achievement in mathematics and reading for girls enrolled in higher amounts of physical education but the findings were not similar among boys. Sallis et $\mathrm{al}^{18}$ reported that despite 
devoting twice as many minutes per week to physical education compared to controls, the health-related physical education programme did not interfere with academic achievement and pointed out that healthrelated physical education may have favourable effects on student's academic achievement.

In our study we found out that physical activity was moderately correlated with academic performance $(\mathrm{r}=$ $+0.49)$ and had a mild negative correlation with BMI $(\mathrm{r}=-0.31)$. We also analysed students by categorizing them into group with no or minimal physical activity and group with physical activity ( $>1$ hour) and found that students with minimal physical activity had a mean academic performance of $67.49 \%, 95 \% \mathrm{CI}$ as $65.85-69.14$, mean BMI of $26.25 \mathrm{~kg} / \mathrm{m}^{2}, 95 \%$ CI as 25.52-26.98, whereas students with physical activity had a mean academic performance of $79.96 \%, 95 \%$ CI as 65.85-69.14, mean BMI of $23.51 \mathrm{~kg} / \mathrm{m}^{2}, 95 \%$ CI as 78.54-81.37. This showed that students who indulged in physical activity had better academic performance and a healthier BMI.

Our study suggests that there exists a definite relationship of physical activity with academic performance and BMI in students with a favourable effect on both. The main limitation of our study was the sampling method and the size. There could always be an argument that children who were able to multi task and manage their time better were able to indulge in both physical activity and studies and perform better as individuals at the outset. Secondly, it was a relatively small convenience sample and lacked representation from children from various economic backgrounds and hence we recommend similar studies at the community level so that the results can be verified. Once validated, the positive effect of physical activity can be emphasized and promoted at all levels so as to achieve both physical and mental wellbeing in this crucial period in a child's life.

\section{Acknowledgement}

The study was conducted under the Short term studentship of Indian Council of Medical Research

\section{References}

1. Jorgensen LG, Nowak M, Ide K, Secher NH. Cerebral blood flow and metabolism. In: Saltin B, Boushel R, Secher N, Mitchell $\mathrm{J}$, editors. Exercise and Circulation in Health and Disease. Champaign, IL: Human Kinetics Publishers; 2000:113-236.
2. Fleshner M. Exercise and neuroendocrine regulation of antibody production: protective effect of physical activity on stress-induced suppression of the specific antibody response. International Journal of Sports Medicine 2000; 21(suppl 1):S14-S19. http://dx.doi.org/10.1055/s-2000-1454 PMid: 10893019

3. Winter B, Breitenstein C, Mooren FC, Voelker K, Fobker M, Lechtermann A et al. High impact running improves learning. Neurobiology of Learning and Memory 2007; 87(4):597-609. http://dx.doi.org/10.1016/j.nlm.2006.11.003 PMid: 17185007

4. Yeung RR. The acute effects of exercise on mood state. Journal of Psychosomatic Research 1996; 40(2):123-41. http://dx.doi.org/10.1016/00223999(95)0055 4-4

5. van Praag H, Kempermann G, Gage FH. Running increases cell proliferation and neurogenesis in the adult mouse dentate gyrus. Nature Neuroscience 1999; 2(3):26670.

http://dx.doi.org/10.1038/6368

PMid: 10195220

6. Schinder AF, Poo M. The neurotrophin hypothesis for synaptic plasticity. Trends in Neurosciences 2000; 23(12):639-45. http://dx.doi.org/10.1016/S01662236(00)01 $672-6$

7. Sibley BA, Etnier JL. The relationship between physical activity and cognition in children: a meta-analysis. Pediatric Exercise Science 2003; 15: 243-56.

8. Penedo FJ, Dahn JR. Exercise and wellbeing: a review of mental and physical health benefits associated with physical activity. Current Opinion in Psychiatry 2005; 18(2):189-93. http://dx.doi.org/10.1097/000015042005030 00-00013

9. Hillman $\mathrm{CH}$, Erickson KI, Kramer AF. Be smart, exercise your heart: Exercise effects 
on brain and cognition. Nature Reviews Neuroscience 2008; 9(1):58-65. http://dx.doi.org/10.1038/nrn2298

PMid: 18094706

10. Singh A, Leone U, Mechelen W, Mai C J. Physical activity and performance at school - A systematic review of the literature including a methodological quality assessment. Archives of Pediatrics Adolescent Medicine 2012; 166(1):49-55. http://dx.doi.org/10.1001/archpediatrics.201 1.716

PMid: 22213750

11. Trudeau F, Shephard RJ. Physical education, school physical activity, school sports and academic performance. International Journal of Behavioral Nutrition and Physical Activity 2008; 5: 10. http://dx.doi.org/10.1186/1479-5868-5-10 PMid: 18298849 PMCid: PMC2329661

12. Groth SW, Beedy DM. Obesity risk in urban adolescent girls: Nutritional intentions and health behaviour correlates. New York State Nurses' Association 2011; 42(0): 15-28.

13. Peralta M, Marques A. The relationship between formal and informal physical activity and the body mass index. British Journal of Sports Medicine 2013; 47(17):e4. http://dx.doi.org/10.1136/bjsports-2013093073.30

14. Eitle T. Do gender and race matter? Explaining the relationship between sports participation and achievement. Social Spectra 2005; 25:177-95. http://dx.doi.org/10.1080/027321705908839 97
15. Coe DP, Pivarnik JM, Womack CJ, Reeves MJ, Malina RM. Effect of physical education and activity levels on academic achievement in children. Medicine and Science in Sports and Exercise 2006; 38(8):1515-9.

http://dx.doi.org/10.1249/01.mss.000022753 7.13175.1b

PMid: 16888468

16. Ahamed Y, Macdonald H, Reed K, Naylor PJ, Liu-Ambrose T, McKay H. School based physical activity does not compromise children's academic performance. Medicine and Science in Sports and Exercise 2007; 39(2):371-6.

http://dx.doi.org/10.1249/01.mss.000024165

$4.45500 .8 \mathrm{e}$

PMid: 17277603

17. Carlson SA, Fulton JE, Lee SM, Maynard ML, Brown DR, Kohl HW et al. Physical education and academic achievement in elementary school: data from the early childhood longitudinal study. American Journal of Public Health 2008; 98(4):721-7. http://dx.doi.org/10.2105/AJPH.2007.11717 6

PMid: 18309127 PMCid: PMC2377002

18. Sallis JF, McKenzie TL, Kolody B, Lewis M, Marshall S, Rosengard P. Effects of health-related physical education on academic achievement :Project SPARK. Res Q Exerc Sport 1999; 70(2):127-34. http://dx.doi.org/10.1080/02701367.1999.10 608030

PMid: 10380244 